\title{
ROLLING WINDOW VaR: AN EVT APPROACH
}

\author{
Andrei RUSUa* \\ a) Babeș-Bolyai University, Faculty of Economics and Business Administration, \\ Cluj-Napoca, Romania
}

Please cite this article as:

Article History:

Rusu, A., 2020. Rolling window VaR: an EVT Received: 5 September 2020 approach. Review of Economic Studies and Research Accepted: 23 September 2020 Virgil Madgearu, 13(2), pp.147-168.

doi: 10.24193/RVM.2020.13.66.

Abstract: In this study, a method of estimating value-at-risk is proposed. This method combines elements of extreme value theory (EVT), the APARCH model (Ding et al. 1993) and the rolling window method. The research was conducted using 20 stock market indexes worldwide during 2006-2019. Value-at-risk was estimated via 12 competing models which were evaluated using 5 tests. The back testing results indicate that the best model was the one which takes into consideration the asymmetric character of financial data (APARCH with skewed normal distribution), the Generalized Pareto Distribution for modeling the tail of the financial returns distribution and the rolling window approach. The methodologies discussed in this paper could provide a useful tool for both financial entities and regulatory authorities.

Key words: Value-at-risk; APARCH; Generalized Pareto Distribution; Back testing JEL Classification: $C_{58}$; G11; G15; G17

(C) 2020 Alma Mater Publishing House. All rights reserved.

* Corresponding author. E-mail address: rusu.andrei24@gmail.com. 
Review of Economic Studies and Research Virgil Madgearu, 202O, 13(2)

\section{References:}

1. Abad, P., Benito, S. and Lopez, C., 2014. A comprehensive review of value at risk methodologies. The Spanish Review of Financial Economics, 12(1), pp.15-32. https://doi.org/10.1016/j. srfe.2013.06.001.

2. Artzner, P., Delbaen, F., Eber, J.M. and Heath, D., 1999. Coherent measures of risk. Mathematical Finance, 9(3), pp.203-228. https:// doi.org/10.1111/1467-9965.00068.

3. Bollerslev, T., 1986. Generalized autoregressive heteroskedasticity. Journal of Econometrics, 31(3), pp.307-327. https://doi. org/10.1016/0304-4076(86)90063-1.

4. Brooks, C., Clare, A.D., Dalle Molle, J.W. and Persand, G., 2005. A comparison of extreme value theory approaches for determining value at risk. Journal of Empirical Finance, 12(2), pp.339-352. https://doi.org/10.1016/j.jempfin.2004.01.004.

5. Chen, Y. and Yu, W., 2020. Setting the Margins of Hang Seng Index Futures on Different Positions using an APARCH-GPD Model based on Extreme Value Theory. Physica A: Statistical Mechanics and its Applications, 544, article no. 123207. https://doi.org/10.1016/j. physa.2019.123207.

6. Christoffersen, P., 1998. Evaluating interval forecasts. International Economic Review, 39(4), pp.841-862. https://doi. org/10.2307/2527341.

7. Daníelsson, J., Jorgensen, B. N., Samorodnitsky, G., Sarma, M. and de Vries, C. G., 2012. Fat tails, VaR and subadditivity. Journal of Econometrics, 172(2), pp.283-291. https://doi.org/10.1016/j. jeconom.2012.08.011.

8. Ding, Z., Granger, C.W.J. and Engle, R.F., 1993. A long memory property of stockmarket returns and a new model. Journal of Empirical Finance, 1(1), pp.83-106. https://doi.org/10.1016/o9275398(93)90006-D.

9. Engle, R.F. and Manganelli, S., 2004. CaViaR: conditional autoregressive value at risk by regression quantiles. Journal of Business and Economic Statistics, 22(4), pp.367-381. https://doi. org/10.1198/073500104000000370.

10. Fong Chan, K. and Grey, P., 2006. Using extreme value theory to measure value-at risk for daily electricity spot prices. International 
RUSU, Rolling Window VaR: AN EVT APPROACH

Journal of Forecasting, 22(2), pp.283-300. https://doi. org/10.1016/j.ijforecast.2005.10.002.

11. Gençay, R. and Selçuk, F., 2004. Extreme value theory and Valueat-Risk: Relative performance in emerging markets. International Journal of Forecasting, 20(2), pp.287-303. https://doi. org/10.1016/j.ijforecast.2003.09.005.

12. Gençay, R., Selçuk, F. and Ulugülyağci, A., 2003. High volatility, thick tails and extreme value theory in value-at-risk estimation. Insurance: Mathematics and Economics, 33 (2), pp.337-356. https://doi.org/10.1016/j.insmatheco.2003.07.004.

13. Gonzalez-Rivera G., Lee T. H. and Mishra, S., 2004. Forecasting Volatility: A Reality Check Based on Option Pricing, Utility Function, Value-at-Risk, and Predictive Likelihood. International Journal of Forecasting, 20(4), pp.629-645. https://doi.org/10.1016/j. ijforecast.2003.10.003.

14. Koenker, R., 2005. Quantile Regression. New York: Cambridge University Press.

15. Kupiec, P.H., 1995. Techniques for verifying the accuracy of risk measurement models. Journal of Derivatives, 3(2), pp.73-84.

16. Lin, P-C. and Ko, P-C., 2009. Portfolio value-at-risk forecasting with GA-based extreme value theory. Expert Systems with Applications, 36(2), pp.2503-2512. https://doi.org/10.1016/j.eswa.2008.01.086.

17. Liu, G., Wei, Y., Chen, Y., Yu, J. and Hu, Y., 2018. Forecasting the value-at-risk of Chinese stock market using the HARQ model and extreme value theory. Physica A: Statistical Mechanics and its Applications, 499, pp.288-297. https://doi.org/10.1016/j. physa.2018.02.033.

18. Marimoutou, V., Raggad, B. and Trabelsi, A., 2009. Extreme value theory and value at risk: application to oil market. Energy Economics, 31(4), pp.519-530. https://doi.org/10.1016/j.eneco.2009.02.005.

19. McNeil, A.J. and Frey, R. 2000. Estimation of tail-related risk measures for heteroscedastic financial time series: an extreme value approach. Journal of Empirical finance, 7(3-4), pp.271-300. https:// doi.org/10.1016/So927-5398(oo)ooo12-8.

20. Morgan, J.P., 1996. Riskmetrics Technical Document, 4th ed. New York: J.P. Morgan.

21. Schaumburg, J., 2012. Predicting extreme value at risk: Nonparametric quantile regression with refinements from extreme 
value theory. Computational Statistics and Data Analysis, 56(12), pp.4081-4096. https://doi.org/10.1016/j.csda.2012.03.016.

22. Wei, Y., Chen, W. and Lin, Y., 2013. Measuring daily Value-at-Risk of SSEC index: A new approach based on multifractal analysis and extreme value theory. Physica A: Statistical Mechanics and its Applications, 392 (1), pp.2163-2174. https://doi.org/10.1016/j. physa.2013.01.032.

23. Yao, F., Wen, H. and Luan, J., 2013. CVaR measurement and operational risk management in commercial banks according to the peak value method of extreme value theory. Mathematical and Computer Modelling, 58 (1-2), pp.15-27. https://doi.org/10.1016/j. mcm.2012.07.013.

24. Yu, W., Yang, K., Wei, Y. and Lei, L., 2018. Measuring Value-atRisk and Expected Shortfall of crude oil portfolio using extreme value theory and vine copula. Physica A: Statistical Mechanics and its Applications, 490, pp.1423-1433. https://doi.org/10.1016/j. physa.2017.08.064.

25. Yamai, Y. and Yoshiba, T., 2002. Comparative Analyses of Expected Shortfall and Value-at-Risk: Their Estimation Error, Decomposition, and Optimization. Monetary and Economic studies, 20(1), pp.87-121. 